

\title{
Stratigraphy and hystricurid trilobites of the Christian Elv Formation (Lower Ordovician) of western North Greenland
}

\author{
Richard A. Fortey and John S. Peel
}

\begin{abstract}
The Christian Elv Formation (Early Ordovician) of Daugaard-Jensen Land, western North Greenland, is formally proposed and recognised from southern Hall Land, in the east, to western Ellesmere Island in the Canadian Arctic Islands, to the west. The formation in its type section includes a shallow water trilobite fauna suggesting a mid-Tremadoc age; conodonts indicate the Rossodus manitouensis Zone of the North American Midcontinent Realm. Two species of hystricurid trilobites are present, of which one, Hystricurus scrofulosus, is described as a new species. The distribution of Hystricurus followed the early Ordovician palaeo-equator and was not confined by palaeocontinental boundaries. Paraplethopeltis is considered to be a subgenus of Hystricurus.

R. A. F., British Museum (Natural History), Cromwell Road, London SW7 5BD, U.K.

J. S. P., Geological Survey of Greenland, Øster Voldgade 10, DK-1350 Copenhagen $K$, Denmark.
\end{abstract}

The description by Christian Poulsen (1927) of Cambrian and Early Ordovician faunas from Inglefield Land, Daugaard-Jensen Land and Washington Land, in north-western Greenland (figs 1-3), remains a classic contribution to arctic palaeontology. The faunas were not collected by Poulsen himself but by the Danish explorer, cartographer and geologist Lauge Koch and his fellow expedition members. Koch visited the area during the Second Thule Expedition (1916-1918) and the Danish Bicentenary Expedition (1920-1923) (Koch, 1940). Despite working with dog-sledges under physically extreme conditions, Koch recognised the principal stratigraphic units within the area and assembled "the most complete collections of early Paleozoic fossils hitherto known from arctic lands" (Poulsen, 1927, prefatory note).

Many Cambrian and Ordovician formation names were introduced by Poulsen (1927) in the course of his description of the faunas, although full descriptions of these formations were first given by Koch at a later date (Koch 1929a, b). The area was not visited again until Johannes C. Troelsen travelled on both sides of Kennedy Channel as a member of the Danish Thule-Ellesmere Land Expedition (1939-1941). Troelsen (1950) revised the early Ordovician stratigraphy proposed by Poulsen (1927) and Koch (1929a, b). He introduced three new formations between the Cape Clay Formation and the Nunatami Formation, based on outcrops along the northern side of Cass Fjord which Koch had mistakenly referred to the Cass Fjord Formation and Cape Clay Formation (figs 2, 3). One of these formations, the Cape Weber Formation of Troelsen (1950), was later renamed the Canyon Elv Formation by Peel \& Cowie (1979). Deep snow prevented Troelsen examining the lower boundary of the Poulsen Cliff Formation which he believed to overlie the Cape Clay Formation in the Cass Fjord area. Thus he overlooked a sequence of strata, here formally described as the Christian Elv Formation, which lie between the Cape Clay Formation and the Poulsen Cliff Formation along the northern side of Cass Fjord.

The Christian Elv Formation was first recognised in the field in Greenland by Niels Henriksen and JSP during 1975 (Henriksen \& Peel, 1976), although strata on Ellesmere Island now assigned to this formation were isolated under the name 'Map-unit 6' by Christie (1967) and Kerr (1968). The name was introduced informally by Henriksen \& Peel (1976) with a brief lithological description and faunal list. It has been mentioned subsequently in regional studies by Peel (1982), Peel \& Christie (1982) and Higgins et al. (in press).

Understandably, Poulsen (1927) was unable to describe fossils from the sequence between the Cape Clay Formation and the Nunatami Formation since Koch had not recognised the intervening formations in the field. Troelsen noted poorly silicified gastropods and the ce- 


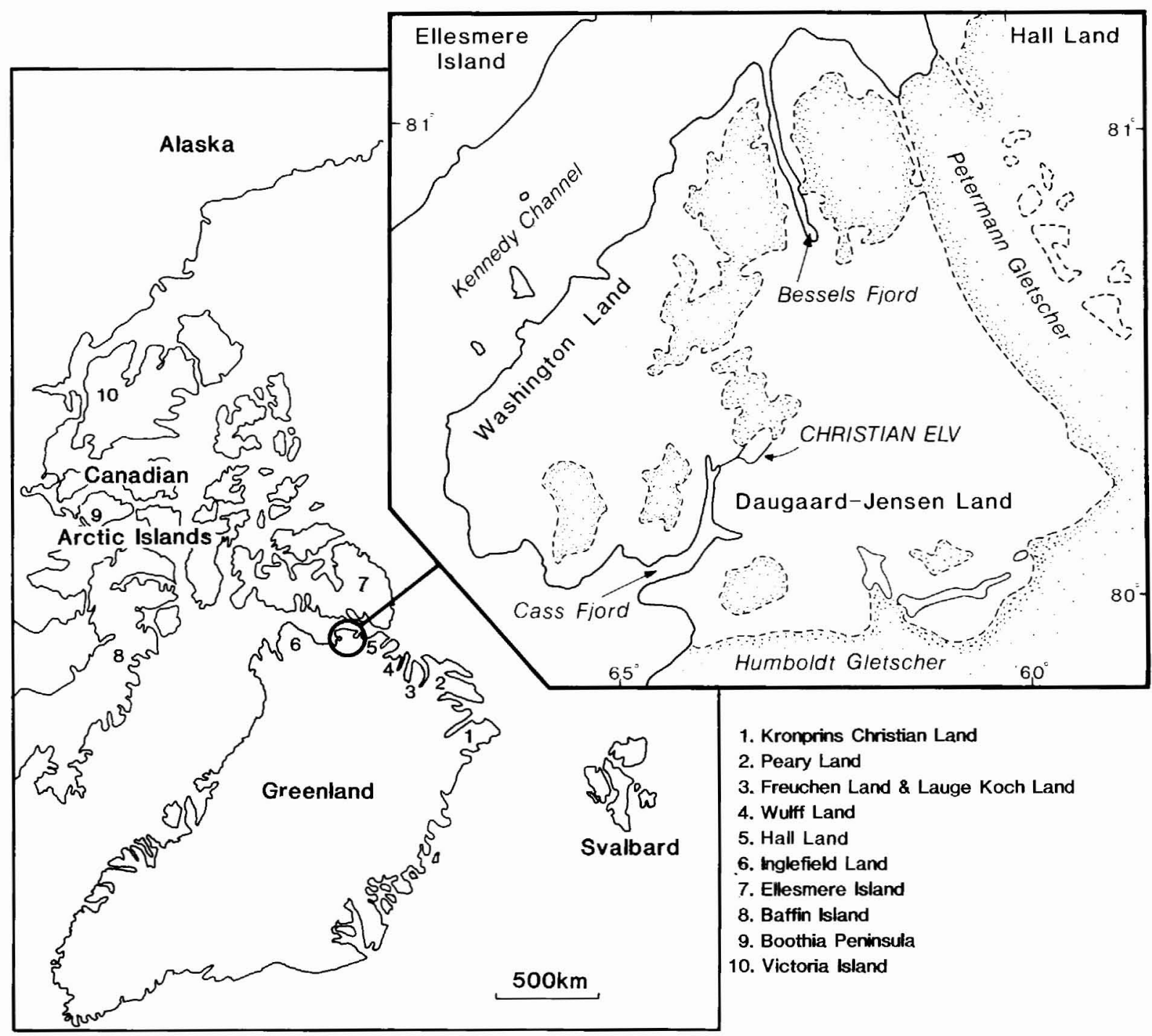

Fig. 1. Greenland and adjacent Arctic Canada showing the location of Christian Elv in Daugaard-Jensen Land.

phalopod Protocycloceras from the Nygaard Bay Formation while Poulsen (in Troelsen, 1950, p. 52) identified the trilobites Petigurus groenlandicum, Bathyurellus teicherti, Pseudomera dactylifera and Bolbocephalus seelyi from the overlying Cape Weber Formation. Indeed, it was these identifications which prompted Troelsen to abandon his manuscript name 'Canyon Elv Formation' in favour of Cape Weber Formation since Poulsen (1937) had recognised a similar fauna in the Cape Weber Formation of East Greenland. Peel \& Cowie (1979) found little reason to maintain the same name (Cape Weber Formation) for two dissimilar and geographically widely separated formations and renamed the Cape Weber Formation as the Canyon Elv Formation.
Fortey \& Peel (in press) describe the fauna of the Poulsen Cliff Formation on the basis of material collected by JSP in 1976, considering that a late Tremadoc age (shelly zone F of the Ross-Hintze, Utah/Nevada scheme) is likely. Samples collected throughout the sequence during 1975 and 1976 were processed for conodonts by V. E. Kurtz and J. F. Miller (various written communications to JSP), although only brief notices of their results have been published (Kurtz, 1977; Kurtz \& Miller, 1978).

The Christian Elv Formation is formally described in the present paper as a prelude to the description of two species of the trilobite Hystricurus collected some $72 \mathrm{~m}$ above the base of the formation (GGU sample 212919). It is of interest in that the trilobites are hystricurids with 




Fig. 2. Geological map of part of southern Daugaard-Jensen Land showing the type locality of the Christian Elv Formation.

large pygidia, which are hitherto not well-known from Laurentia. It is also possible to associate cranidia, free cheeks and pygidia in this material; thus these hystricurids are better known than most. This opportunity is taken to discuss the palaeogeography of hystricurid trilobites which is of interest in the debate about the relationship between continental configuration and faunal distribution in the Ordovician.

\section{Christian Elv Formation}

Name. After Christian Elv, a river in Daugaard-Jensen Land named after Professor Christian Poulsen (18961975) and flowing westward into the head of Cass Ford (figs 1, 2).

History. This name was introduced by Henriksen \& Peel (1976), with a short description, but the formation was not formally defined. On account of their restricted distribution in the inner part of Cass Fjord, strata assigned to the Christian Elv Formation were overlooked in earlier descriptions (Poulsen, 1927; Koch, 1929a, b; Troelsen, 1950, 1956). General descriptions are given by Peel (1982), Peel \& Christie (1982), Sønderholm \& Due (1985) and Higgins et al. (in press). Ineson \& Peel (1987) assigned the Christian Elv Formation to the Ryder Gletscher Group.

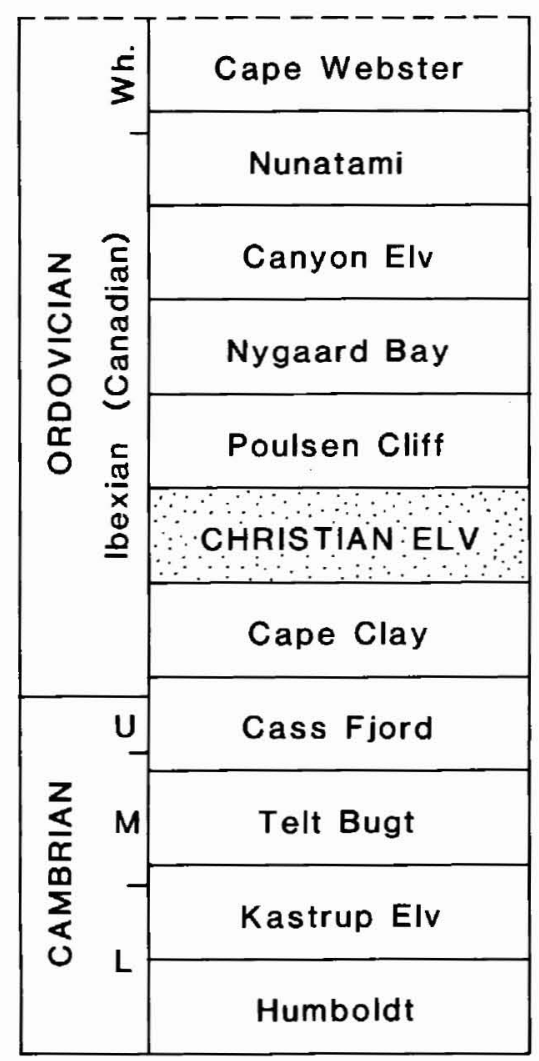

Fig. 3. Cambrian and Lower Ordovician formations of Daugaard-Jensen Land and Washington Land. Wh, Whiterockian.

Type section. South side of Christian Elv, DaugaardJensen Land (figs 2, 4, 5).

Boundaries. The Christian Elv Formation conformably overlies relatively massive weathering, buff limestones of the Cape Clay Formation. The precise boundary is covered by $2-3 \mathrm{~m}$ of talus in the type section but a recessive bed of green shale with thin limestone bands occurring at or immediately above the base of the Christian Elv Formation forms a distinctive mapping horizon (fig. 5). The formation is conformably overlain by the Poulsen Cliff Formation, a recessive unit dominated by shales, anhydrite and dolomite. The boundary is drawn at the top of a prominent sandstone unit (thickness $24 \mathrm{~m}$ in the type section; fig. 4). Approximately $10 \mathrm{~m}$ of very pale dolomites and limestones, with silty laminae and sporadic black cherts occurring above the sandstone in the type section, were also assigned to the Christian Elv Formation by Henriksen \& Peel (1976) and subsequent authors but these strata are here referred to the Poulsen Cliff Formation. 


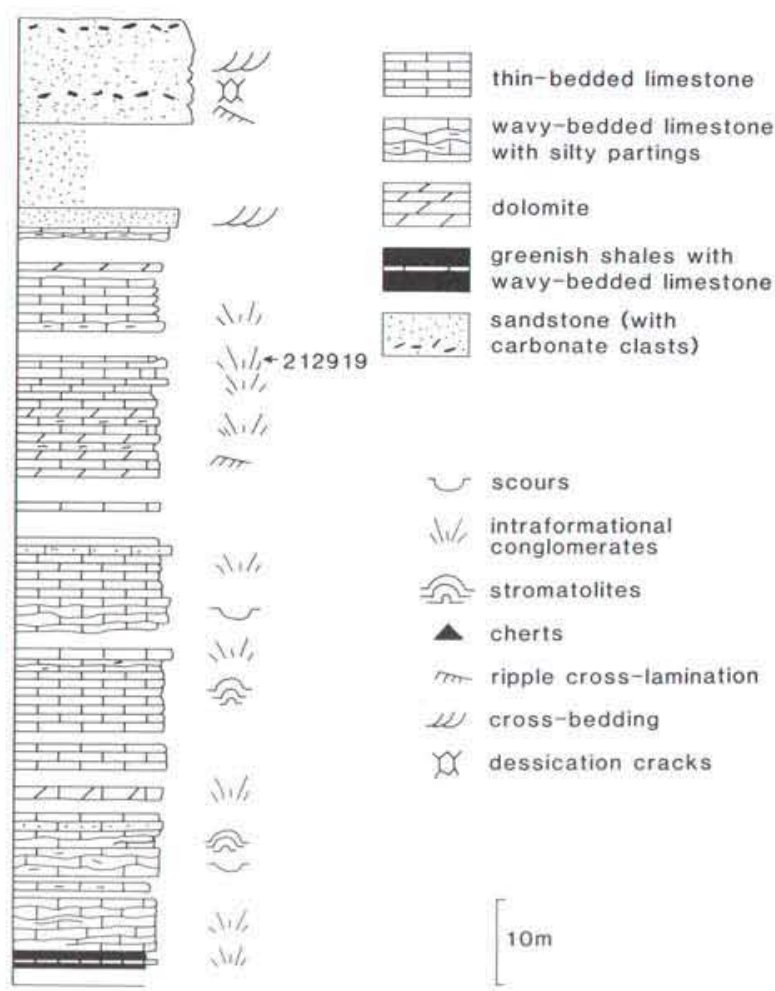

Fig. 4. Type section of the Christian Elv Formation showing the location of GGU sample 212919, see also fig. 2.

Thickness. Henriksen \& Peel (1976) reported a thickness of $140 \mathrm{~m}$, based on measurement of the section at Christian Elv. This figure corresponds to the entire measured sequence, however, including strata assigned to both the Cape Clay Formation and the Poulsen Cliff Formation. Following slight modification of their concept of the formation, discussed in the previous section, the thickness of the formation in its type section is $112 \mathrm{~m}$.

Lithology. The Christian Elv Formation can be subdivided into three members. The basal member consists of greenish shales with wavy-bedded limestone, exposed to almost $2 \mathrm{~m}$ in the type section but with 2-3 m of talus covering the boundary with the underlying Cape Clay Formation. The middle member $(84 \mathrm{~m})$ consists mainly of thin-bedded lime mudstones, with subsidiary dolomites and arenaceous limestones. The lime mudstones $(1-10 \mathrm{~cm})$ are often irregularly wavy-bedded with shaly partings; scours, and pockets and thin beds of intraformational conglomerate are common. Other sedimentary features include stromatolites, dessication cracks and ripple cross-lamination. Interspersed beds of darker lime mudstone and yellowish weathering beds of

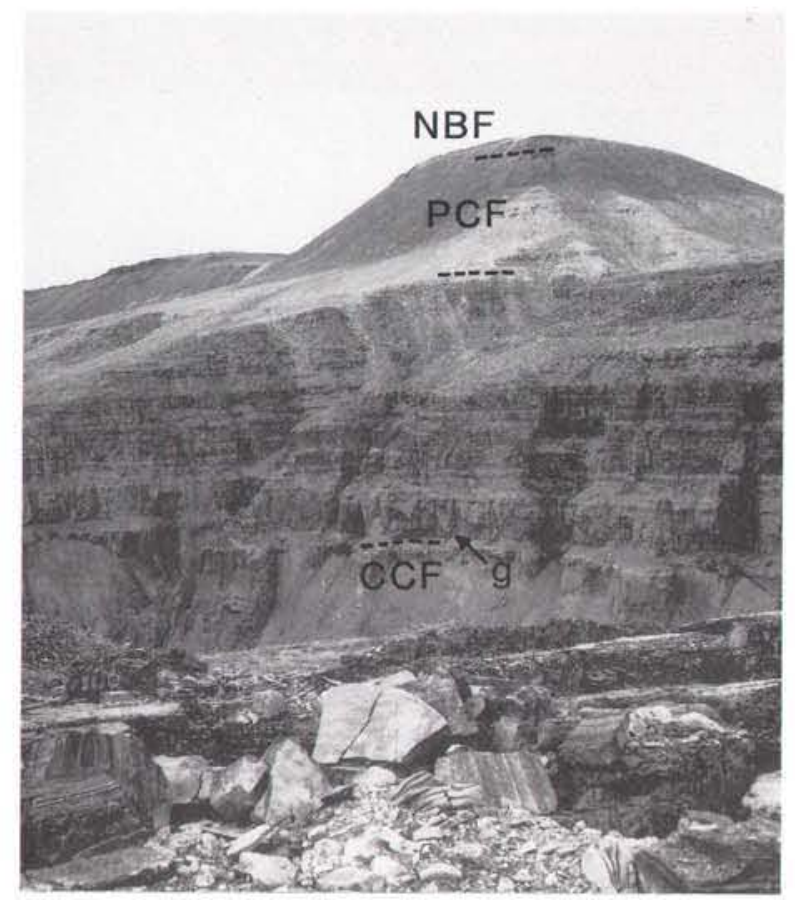

Fig. 5. View north-west across Christian Elv from the type locality of the Christian Elv Formation. Note the prominent greenish shale bed $(\mathrm{g})$ at the junction with the underlying Cape Clay Formation (CCF) and the pale weathering sandstone member forming the top of the formation. Pale weathering, recessive strata above the Christian Elv Formation belong to the Poulsen Cliff Formation (PCF), although the Nygaard Bay Formation (NBF) forms crags at the hill tops (photo: Niels Henriksen, 1975).

dolomite give the member a striped appearance. The uppermost member $(24 \mathrm{~m})$ consists of pale buff to yellowish weathering, fine-grained to medium-grained sandstone with well-rounded grains of quartz. Bedding is variable, usually $2-5 \mathrm{~cm}$, but occasional beds up to 20 $\mathrm{cm}$ thick are present. Conglomeratic beds contain tabular clasts of limestone mainly $1-2 \mathrm{~cm}$ in diameter but rarely up to $10 \mathrm{~cm}$; weathering of the clasts often produces a cavernous appearance. Ripple cross-lamination, dessication cracks and small-scale cross-bedding are widespread.

Distribution. From Cass Fjord north-east across Daugaard-Jensen Land to the nunataks on the eastern side of Petermann Gletscher (fig. 1). To the west, in eastern Ellesmere Island in Arctic Canada, 'Map-unit 6' of Christie (1967) and Kerr (1968) is refered to the Christian Elv Formation. The former author ascribed a thickness of 300 feet $(c .84 \mathrm{~m})$ to the formation but did not record a sandstone unit at the top. Kerr (1978) mea- 
sured a thickness of 465 feet (c. $134 \mathrm{~m}$ ) of which the sandstone unit at the top accounted for about $38 \mathrm{~m}$. In Canada, the Christian Elv Formation is overlain by the Baumann Fiord Formation, equivalent to the Poulsen Cliff Formation and Nygaard Bay Formation of Greenland (Peel \& Christie, 1982).

\section{Age of the Christian Elv Formation}

Neither of the hystricurid species described below from the Christian Elv Formation can be definitely identified elsewhere. Nonetheless, it is possible to infer something of the age of the formation by comparison with other hystricurid faunas. The detailed taxonomic comparisons given below show that in all early Ibexian hystricurids where the pygidium is known it is comparatively small. This applies to the selection of hystricurid pygidia from shelly fauna Zone B illustrated by Ross (1951, Pl. 9, figs 1-13) and Hintze (1953, Pl. 6, figs 20, $21,23-26)$. The same pygidia show a narrow and convex posterior pygidial border. Larger Hystricurus pygidia with wider pleural fields appear in the Utah/Nevada sections at shelly fauna Zone $\mathrm{E}$, and continue into shelly fauna Zone $\mathrm{F}$. The closest match for the pygidium of $H$. scrofulosus is an undescribed specimen from Zone $\mathrm{E}$ described by Ross (1951, Pl. 19, fig. 13). Another similar pygidium from the McKay Group in British Columbia is part of Kobayashi's (1955) 'Kainella-Evansaspis' fauna overlying a Symphysurina Zone fauna, and likely to be an equivalent of shelly fauna Zone $\mathrm{C}$ or somewhat younger. In Tasmania (Jell \& Stait, 1985) the species $H$. lewisi is similar to H. scrofulosus. The age of the Tasmanian fauna is not certain, but it is not early Tremadoc. The most similar species of Hystricurus (Paraplethopeltis) to that from the Christian Elv Formation is from Zone $\mathrm{C}$ in Utah. A similar cranidium from New Mexico is from the Big Hatchet Formation which Flower (1969) regards as 'late early Canadian' age (shelly fauna Zone D). This evidence is consistent with the Christian Elv fauna being within the interval shelly fauna Zone $\mathrm{C}$ to Zone E. This is supported also by the age of the overlying Poulsen Cliff Formation which was given as Zone F or G by Fortey \& Peel (in press), and with the presence of Symphysurina and hystricurids with small pygidia in the underlying formation. This age would equate approximately with the middle part of the Tremadoc Series.

M. P. Smith (written communication, 1989) notes that conodont faunas show no major changeover at the boundary between the Cape Clay Formation and the Christian Elv Formation, although there is a noticable reduction in diversity from the higher levels of the older unit. The uppermost levels of the Cape Clay Formation contain Cordylodus angulatus Pander, C. intermedius Furnish, C. lindstromi Druce \& Jones, Rossodus mani- touensis Repetski \& Ethington and Variabiloconus bassleri (Furnish). Only the latter two species continue into the Christian Elv Formation, to a height of $72 \mathrm{~m}$ above the base where they occur together with the species of Hystricurus described below (GGU sample 212919). Other species ranging across the boundary include Teridontus nakamurai Nogami (which has been recovered to a height of $42 \mathrm{~m}$ above the base), Oneotodus simplex Furnish (to $62 \mathrm{~m}$ ) and a characteristic, horseshoeshaped, new species of Clavohamulus (to $72 \mathrm{~m}$ ). This assemblage of taxa, and also that in the underlying Cape Clay Formation, unequivocally indicates a position within the Rossodus manitouensis Zone of Landing et al. (1986). This zone is a replacement for the widely used, but informal, Fauna $\mathrm{C}$ of Ethington \& Clark (1971) and the Loxodus bransoni Interval of Ethington \& Clark (1982).

The single sample for conodont processing available from the uppermost $50 \mathrm{~m}$ of the Christian Elv Formation and the lower $40 \mathrm{~m}$ of the overlying Poulsen Cliff Formation has not yielded a fauna. The overlying conodont zone, the still informal conodont Fauna D of Ethington \& Clark (1971), is introduced at about $40 \mathrm{~m}$ above the base of the Poulsen Cliff Formation where Glyptoconus quadraplicatus (Branson \& Mehl) and Eucharodus parallelus (Branson \& Mehl) have their lowest occurrences.

The age suggested by the hystricurid trilobites is understandably less precise than the conodont age, as noted above, but it is not inconsistent with the conodont evidence of the Zone of Rossodus manitouensis.

\section{Systematic descriptions}

Family Solenopleuridae Angelin, 1854

Genus Hystricurus Raymond, 1913

Type species. H. conicus Billings, 1859.

Remarks. The genus Paraplethopeltis Bridge \& Cloud has been regarded as unrelated to Hystricurus, being placed in the Family Plethopeltidae. However, a species from the Christian Elv Formation, described below as H. (Paraplethopeltis) sp. nov. A, appears to show a combination of characters which link Paraplethopeltis and Hystricurus. This species has a long, sloping preglabellar field, and is generally rather effaced. However, the glabellar form and border furrow are much like that of typical Hystricurus. Paraplethopeltis is typically smooth dorsally, but sp. nov. A shows few, rather subdued tubercles. The pygidium is similar to those attributed to Paraplethopeltis? species from Utah by Hintze (1953). The cranidium of the type species of Paraplethopeltis, $P$. obesa Bridge \& Cloud, is highly effaced, show- 
ing neither the border furrow nor the occipital ring clearly (Bridge \& Cloud, 1947). However, there seem to be a range of species connecting this aspect with more typical Hystricurus, by way of such species as $P$. genacurva Hintze and $P$. sp. nov. A. Accordingly, Paraplethopeltis is regarded as a close relative of Hystricurus, and this is recognised by according it subgeneric status here.

\section{Hystricurus (Hystricurus) scrofulosus sp. nov.}

\section{Fig. 6}

Holotype. Pygidium, MGUH 18.993 from GGU sample 212919.

Figured paratypes. Cranidia, MGUH 18.990-18.992, 18.994 , 18.996, 18.997; free cheek, MGUH 18.989; pygidium, MGUH 18.995; all from GGU sample 212919.

Other material. Six cranidia and two pygidia in GGU sample 212919.

Name. Latin, 'diseased', referring to sculpture.

Diagnosis. Hystricurus with large pygidium. Surface sculpture on cranidium consisting of tubercles of two sizes. Genal spine short. Large pygidium without prominent border, tuberculate, and large single tubercles on each of four segments near edge of pleural fields.

Description. Cranidia cover a size range from $3 \mathrm{~mm}$ to over $1 \mathrm{~cm}$. Largest pygidia (fig. $6 \mathrm{~J}$ ) are nearly as long as the largest cranidia indicating that the species was probably subisopygous. Small cranidia are the more convex, with deeper axial furrows. At all sizes glabella is parabolic, without a truncate anterior margin. Occipital ring well-defined. Only faint indication of posterior pair of glabellar furrows opposite posterior parts of palpebral lobes. Preglabellar field of about the same (sag.) or slightly greater width as anterior border, as seen in dorsal view; downsloping and gently convex. Anterior border convex and deeply defined, not upward arched. Palpebral lobes well-removed from glabella, set at about mid-cranidial length, of moderate size for genus (about 0.5 length of pre-occipital glabella) not strongly curved, and posterior ends well in front of lateral edges of occipital ring. Eye ridges faint, or absent. Anterior sections of facial sutures divergent (about $30^{\circ}$ to sag. line) in front of palpebral lobes; posterior sections highly so, defining downsloping postocular cheeks of similar width (tr.) as occipital ring. Posterior border elevated, widening laterally.

Free cheek with short, pointed genal spine. Lateral border furrow continues into genal angle where it meets short section of posterior border furrow at an angle of about $70^{\circ}$. Lateral border widens slightly towards genal angle.

The most complete pygidum is almost twice as wide as long. Axis occupies 0.8 pygidial length, tapers gently to broad (tr.) terminal piece which shows indications of being divided sagitally into two lobes. Four axial rings, only slightly decreasing in width (sag.) posteriorly. Ring furrows much deeper laterally, probably representing apodemes. Pleural fields clearly divided into four segments, with strong pleural, and weak interpleural furrows. A notable feature is the presence of a prominent tubercle on each segment, near the outside edge of each posterior pleural band. Posterior margin of pygidium slopes steeply downward. The only indication of a border is a gently convex peripheral band.

Surface sculpture over whole surface consists of small and large tubercles, the former more numerous. The tubercle pattern is reflected also on the internal mould. Tubercles, however, do not extend into the axial or border furrows. A similar pattern is seen on the small cranidium (fig. 6L) and it does seem, therefore, to be a consistent specific character. The tubercles are poorly developed over the mid-part of the preglabellar field, and there is a smooth band inside the lateral border furrow on the free cheek.

Discussion. There are some problems in fully discussing Hystricurus species with granulate or tuberculate surface sculpture because several species have been named without associated free cheeks and pygidia. The type species, $H$. conicus (Billings), apparently has a more rapidly tapering glabella than the species from the Christian Elv Formation, as well as palpebral lobes that extend further posteriorly, and comparatively narrow pygidial pleural fields. Well-preserved, silicified species described from the early Ibexian of Utah and Nevada by Ross (1951) and Hintze (1953) have pygidia only doubtfully assigned (where recognised at all). $H$. genalatus Ross is most similar to our species in cranidial proportions, but has longer genal spines; the lateral border furrow also becomes obsolete near the genal angle. Isolated pygidia from shelly fauna Zone B in the western U.S.A. apparently are all small (Ross, 1951, Pl. 9, figs 1-19) with well defined, narrow posterior borders, regardless which species they may belong to. It is likely that the species from Greenland was subisopygous. A somewhat younger species from Utah, $H$. oculilunatus Ross, also has a short genal spine, but its palpebral lobes extend far back producing a narrow (exsag.) postocular cheek, and the genal border carries ridges rather than tubercles. The new species has a characteristic 


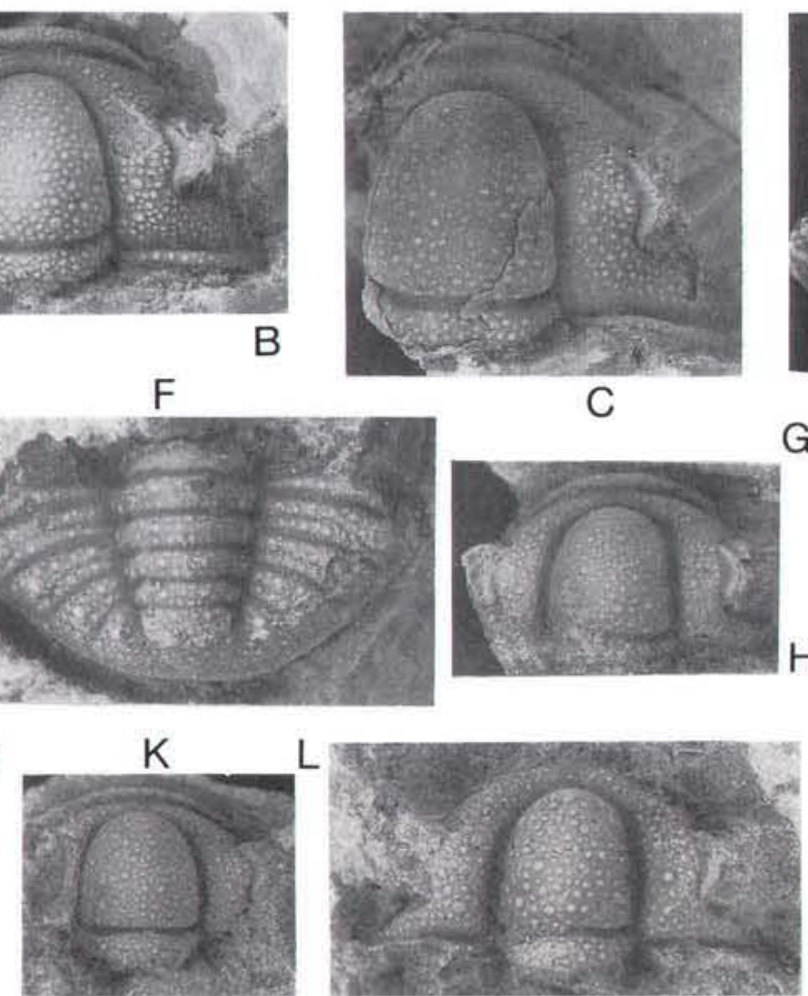

C
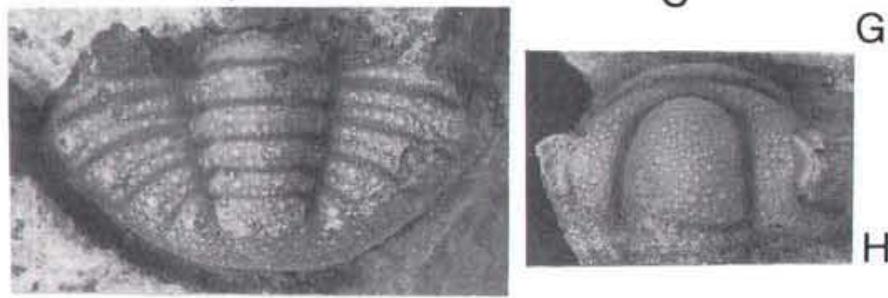

G
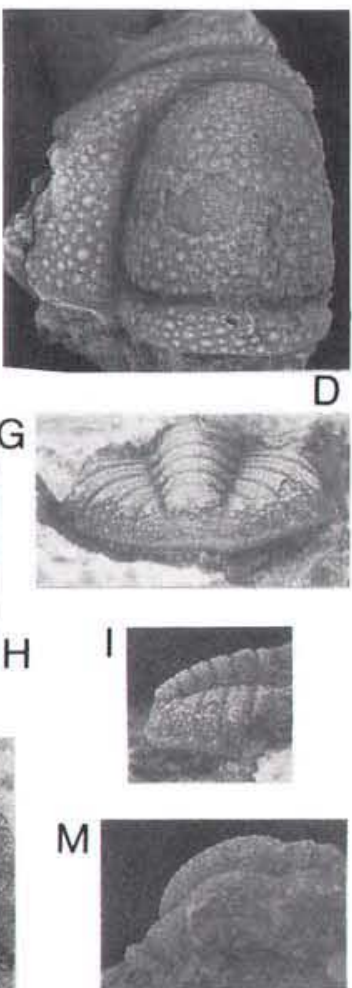

Fig. 6. Hystricurus (Hystricurus) scrofulosus sp. nov. All specimens from GGU sample 212919, Christian Elv Formation, Christian Elv, Daugaard-Jensen Land. A, cheek, $\times 4$, MGUH 18.989; B, E, incomplete cranidium, $\times 3$, dorsal, anterior views, MGUH 18.990; C, incomplete cranidium, $\times 4$, MGUH 18,991; D, largest cranidium, × 3, MGUH 18.992; F, G, I, best preserved pygidium, dorsal, $\times 6$, and posterior and lateral views, $\times 4$, holotype, MGUH 18.993; H, incomplete cranidium, $\times 3$, MGUH 18.994; J, large fragmentary pygidium, $\times 3$, MGUH 18.995; K, M, cranidium, $\times 4$, dorsal and lateral views, MGUH 18.996; L, small cranidium, $\times 6$, MGUH 18.997 .

tubercle pattern of two sizes - large and small - on the glabella. Species with coarser and more uniform tuberculation include $H$. genalatus Ross, $H$. paragenalatus Ross and $H$. robustus Ross from western U.S.A. and $H$. paucituberculatus Fortey from western Newfoundland (Ross, 1951; Fortey, 1983). Of species previously known from Greenland (Poulsen, 1927, 1937), H. ravni Poulsen from the uppermost Cass Fjord Formation of Daugaard-Jensen Land (early Ibexian), has short genal spines like the new material, but has a rather strongly tapering and anteriorly truncate glabella; apparently also the pygidium of $H$. ravni is comparatively small, as seems to be the case with all the early Ibexian species. An unnamed, larger pygidium illustrated (from Zone 'E') by Ross (1951, Pl. 19, figs 13, 14, 17) is probably the closest match for that of the Greenland species in the collections from the western U.S.A.

Tasmanian species of Hystricurus, one of which was originally described by Kobayashi (1940), have been described by Jell \& Stait (1985) and these apparently do have larger pygidia. H. timsheaensis (referred to as $H$. penchiensis $\mathrm{Lu}$ in their text) has large eyes compared with the Greenland species, and the lateral genal border carries raised ridges. However, H. lewisi Kobayashi is exceedingly like our species in its general proportions and size of genal spine; one specimen (Jell \& Stait, 1985, PI. 2, fig. 11) apparently shows similar glabellar sculpture. H. lewisi differs in its consistently wide palpebral rims, and the pygidium is, at most, only weakly tuberculate. Nonetheless, the resemblance between such widely separated taxa is remarkable.

A species from the North China platform, $H$. penchiensis Lu (see Zhou \& Fortey, 1986), also has a comparatively large pygidium; the eye ridges on this species are strongly developed and the palpebral lobes are highly curved. One other species has a similar surface sculpture, H. wilsoni Gobbett from Spitsbergen (Gobbett, 1960). This species has large, curved palpebral lobes and occipital spines. Among more incompletely known species, $H$. elevatus Heller has an upward- 
curved anterior border and $H$. abruptus Cullison has a rectangular glabella and a small pygidium. Both are from Missouri (Cullison, 1944; Heller, 1956)

$H$. platypleurus Kobayashi is known only from a pygidium, but small though this is, it shows a flattened border. Kobayashi (1955), however, did describe a pygidium of a second species (as Dimeropygiella eos) showing a somewhat bifid terminal piece on the axis, but otherwise like a hystricurid. It resembles the pygidium of $\mathrm{H}$. scrofulosus but has a flattened border and less prominent tubercles. Kobayashi's (1934) species from Korea all have larger eyes than the Greenland form. Finally, there is $H$. missouriensis Ulrich, from the Gasconade Dolomite, Missouri, described from a cranidium (Ulrich in Bridge, 1930). The proportions of this cranidium are like that of $H$. scrofulosus but for the fact that the anterior branches of the facial sutures appear to converge forwards on the Missouri specimen. This may, however, be a matter of incomplete preparation. The tubercular ornament is strongly present over the mid part of the preglabellar field in $\mathrm{H}$. missouriensis, and the palpebral furrows (Ulrich in Bridge, 1930, PI. 21, fig. 1) are nearly straight. It is not likely therefore that our species and $H$. missouriensis are conspecific, although more information on the latter is required. $H$. scrofulosus is one of a small group of hystricurids with comparatively large pygidia, but it is distinct from all described species.

\section{Subgenus Hystricurus (Paraplethopeltis) Bridge \& Cloud, 1947}

\section{Hystricurus (Paraplethopeltis) sp. nov. A}

Fig. 7

Figured material. Cranidia, MGUH 18.998, 18.999, 19.002; free cheek, MGUH 19.000; pygidium, MGUH 19.001; all from GGU sample 212919.

Other material. Two cranidia in GGU sample 212919.

Description. Cranidia are more convex than those of $H$. scrofulosus because of the steeply sloping, long preglabellar field which, in dorsal view, is more than twice (sag.) length of cranidial border. Glabella with parabolic outline, lacking glabellar furrows. Occipital ring welldefined. Palpebral lobes with curved outline and welldefined rims; at most half length (sag.) of pre-occipital glabella. Anterior cranidial border not deeply defined, and continuing downward slope of preglabellar field. Posterior border furrow comparatively deep. Posterior border widens noticeably laterally. Faint eye ridges present. Postocular cheeks of transverse width equal to, or slightly less than that of occipital ring.

Free cheek with gently curved genal spine of moderate length. Lateral border furrow not deeply impressed.
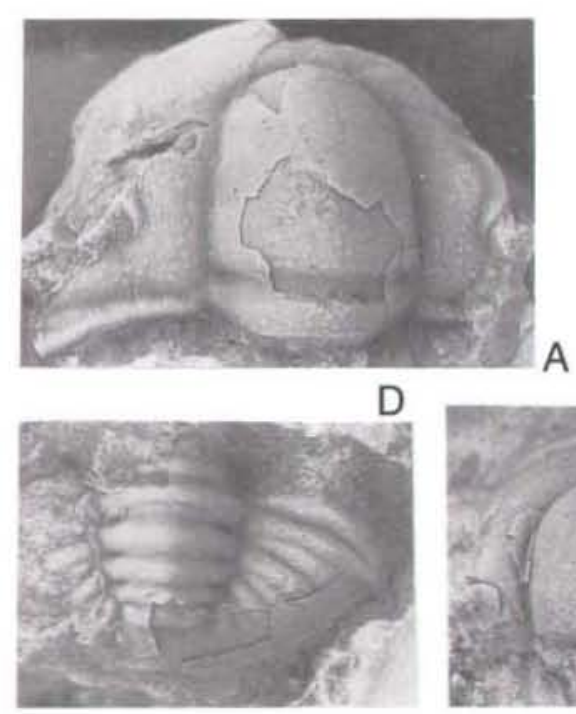

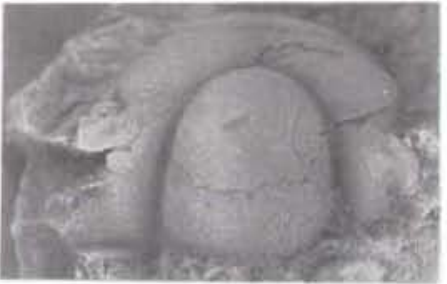

B

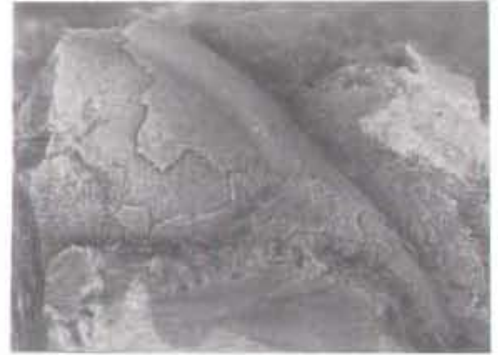

C

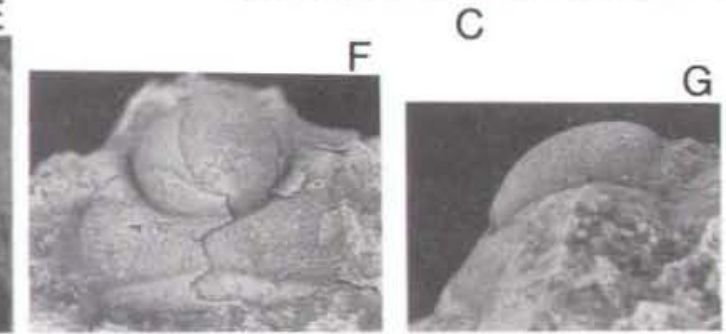

Fig. 7. Hystricurus (Paraplethopeltis) sp, nov. A. All specimens from GGU sample 212919, Christian Elv Formation, Christian Elv, Daugaard-Jensen Land. A, largest cranidium, incomplete on right, $\times 4$, MGUH 18.998; B, incomplete cranidium, $\times 4$, MGUH 18.999; C, free cheek, $\times$ 4, MGUH 19.000; D, pygidium, $\times$ ?, MGUH 19.001; E, F, G, incomplete cranidium in dorsal, anterior and lateral views, $\times 3$, MGUH 19.002 . 
Pygidium known from one incomplete example. Gently tapering axis extends to two-thirds pygidal length. Four exial rings are well-defined by ring furrows, especially laterally. Short (sag.) terminal piece about three times as wide as long. The first ring furrow retains an impression of an articulating half ring. Pleural fields horizontal near axis, steeply downturned peripherally. Pleural and interpleural furrows of first three segments are clearly defined; fourth segment obscure. Pleural furrows are inclined progressively steeply backwards posteriorly. Marginal rim lacking.

The surface sculpture consists of rather faint and scattered tubercles on the cranidium. These do not extend to the free cheek nor on to the borders. Possibly with the exception of the first segment, the pygidium has a smooth dorsal surface.

Discussion. Although there are cranidia, a free cheek and an incomplete pygidium for this species, it is considered that the material is hardly adequate to justify the formal erection of a new species; hence open nomenclature is employed. Species here attributed to the subgenus Paraplethopeltis are widely distributed over the Laurentian platform. The Texan type species, $P$. obesa Bridge \& Cloud (and also P. depressa Bridge \& Cloud; Cloud \& Barnes, 1948) has a poorly defined occipital ring and marginal cranidial rim compared with the species from the Christian Elv Formation (Bridge \& Cloud, 1947). P. carinifera Flower is like the type species in these characters. A closer comparison is with species from Utah described by Hintze (1953) which are closely similar in the development of cephalic furrows, in the length of the preglabellar field and size of the palpebral lobes. $P$. genacurva Hintze has long and curved genal spines, however, and $P$. ?generecta Hintze is much more like the Greenland species in this regard. Both the Utah species are reported as being without surface sculpture, whereas there are very subdued tubercles on the Greenland material. The pygidial axis of both Utah species is longer, and Hintze states that there may be more than four axial rings. So it is not likely that either of the Utah species are conspecific with that from Greenland, although $P$. ?generecta is close. Flower (1969, Pl. 2 fig. 5) illustrated a poorly preserved cranidium from the Big Hatchet Formation, New Mexico, which is like the Greenland specimens, but for a slightly shorter preglabellar field.

\section{Distribution of hystricurid trilobites}

Hystricurids are a characteristic element in Early Ordovician (Tremadoc) faunas. They appear to be confined to inshore facies in carbonate environments in strata exhibiting features of intertidal sedimentation or with stromatolites, as they are in the Christian Elv Formation. The genus Hystricurus was first described from New York State and has since been recorded from many localities in Canada and the U.S.A. A stratigraphic sequence of hystricurids was described from Utah and Nevada by Ross (1951) and Hintze (1953). They appear to be limited to the earlier Ibexian (Canadian of some authors) but they may include species ancestral to Dimeropygidae and Bathyuridae (Fortey \& Owens, 1975), i.e. they may represent a paraphyletic group. In any case they appear quite suddenly in platform successions, presumably accompanying the basal Ordovician transgression. Plausible hystricurid ancestors may be found among the 'generalised ptychoparioids' of the later Cambrian, although nobody has yet described a phylogenetic sequence. Many of them are coarsely tuberculate, which is a common feature among inshore trilobites of the carbonate platform.

Hystricurids are an almost invariable component of shallow water carbonate sediments of Early Ordovician age and they are often accompanied by the effaced primitive cyclopygacean Symphysurina. Hystricurids are recorded from New Mexico, Nevada, Utah, Texas, Montana, New York State, the Beekmantown of Quebec, western Newfoundland, and several localities in western Canada (see reference list). Poulsen (1927, 1937) described several species from Greenland, and hystricurids have also been described from the Kirtonryggen Formation in North Spitsbergen (Gobbett, 1960). Like the bathyurids later in the Ordovician they effectively define Early Ordovician tropical palaeolatitudes. They are not known from contemporary deposits in Scandinavia and the Russian Platform, supposedly at temperate palaeolatitudes, nor from the western part of Gondwana, at higher palaeolatitudes. Hystricurids, however, are recorded outside the Laurentian palaeocontinent, from the North China Platform, from Korea, and from Tasmania (references below). According to most continental reconstructions all these localities lay close to the palaeo-equator (fig. 8). It seems, therefore, that hystricurids, like the bathyurid Peltabellia discussed by Fortey \& Peel (in press), were not confined to a single continental block, but were able to extend widely around the palaeo-equator. Curiously, Symphysurina, a common associate of Hystricurus in Laurentia, was apparently confined to that continent.

Acknowledgements. Collaboration with Niels Henriksen during the 1975 field season is gratefully acknowledged. M. P. Smith reviewed the manuscript and kindly provided the discussion of conodont biostratigraphy. Figured specimens are deposited in the type collection (MGUH prefix) of the Geol- 


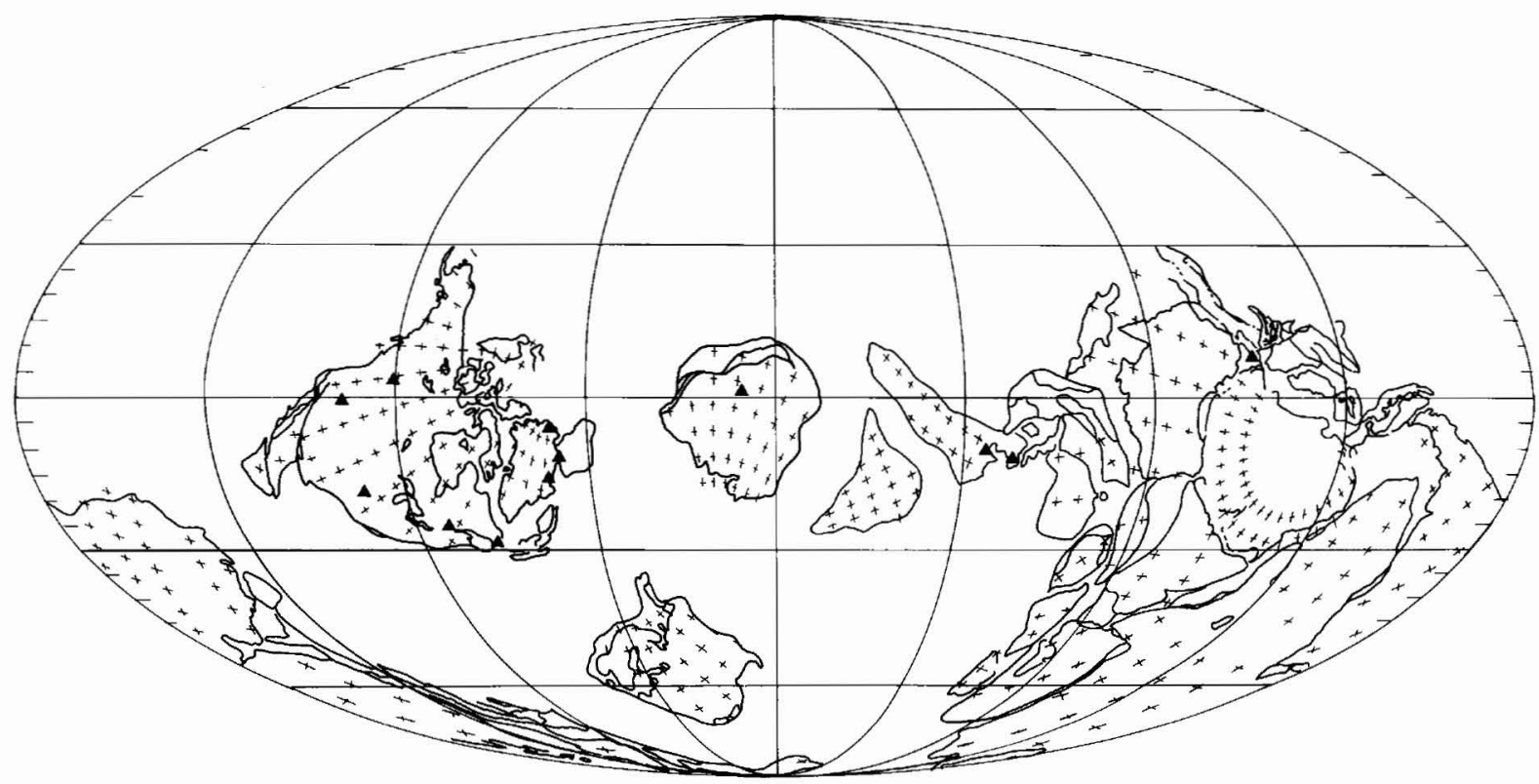

Fig. 8. Distribution of Hystricurus (triangles) on Early Ordovician palaeogeography (after Scotese, in press) showing how the genus is widespread in equatorial palaeolatitudes but independent of continental distribution. See text for references.

ogical Museum, Copenhagen. Non-figured material is retained within the collections of the Geological Survey of Greenland (GGU).

\section{References}

Bridge, J. \& Cloud, P. E. 1947: New gastropods and trilobites critical in the correlation of Lower Ordovician rocks. Am. J. Sci. 245, 545-559.

Christie, R. L. 1967: Bache Peninsula, Ellesmere Island, Arctic Archipelago. Mem. geol. Surv. Canada 347, 63 pp.

Cloud, P. E. \& Barnes, V. E. 1948: The Ellenburger Group of central Texas. Publs Univ. Texas Bur. Econ. Geol. 4621, $1-405$.

Cullison, J. S. 1944: The stratigraphy of some Lower Ordovician formations of the Ozark Uplift. Bull. Univ. Missouri School Mines Metall. 15, 1-112.

Ethington, R. L. \& Clark, D. L. 1971: Lower Ordovician conodonts in North America. Mem. geol. Soc. Am. 127, 63-82.

Ethington, R. L. \& Clark, D. L. 1982: Lower and Middle Ordovician conodonts from the Ibex area, western Millard County, Utah. Brigham Young Univ. geol. Stud. 28(2), 155 pp. [Cover date 1981].

Flower, R. H. 1969: Some El Paso guide fossils. Mem. New Mexico Bur. Mines Min. Res. 22, 1-19.

Fortey, R. A. 1983: Cambrian-Ordovician trilobites from the boundary beds in western Newfoundland and their phylogenetic significance. Spec. Pap. Palaeontology 30, 179-211.

Fortey, R. A. \& Owens, R. M. 1975: Proetida-a new order of Trilobites. Fossils \& Strata 4, 227-239.
Fortey, R. A. \& Peel, J. S. in press: Early Ordovician trilobites and molluscs from the Poulsen Cliff Formation, Washington Land, western North Greenland. Bull. geol. Soc. Denmark.

Gobbett, D. J. 1960: A new species of trilobite from the Lower Oslobreen Limestone. Geol. Mag. 97, 457-460.

Heller, R. L. 1956: Stratigraphy and palaeontology of the Roubidoux Formation of Missouri. Bull. Missouri Geol. Surv. 2nd Ser. 35, 1-118. [Cover date 1954].

Henriksen, N. \& Peel, J. S. 1976: Cambrian - Early Ordovician stratigraphy in south-western Washington Land, western North Greenland. Rapp. Grønlands geol. Unders. 80, $17-23$

Higgins, A. K., Ineson, J. R., Peel, J. S., Surlyk, F. \& Sønderholm, M. in press: The Franklinian basin in North Greenland. In Trettin, H. P. (edit.) The Innuitian region. The geology of North America E. Ottawa: Geol. Surv. Canada.

Hintze, L. F. 1953: Lower Ordovician trilobites from western Utah and eastern Nevada. Bull. Utah Geol. Miner. Surv. 48, 1-249.

Ineson, J. R. \& Peel, J. S. 1987: Cambrian platform - outer shelf relationships in the Nordenskiöld Fjord region, central North Greenland. Rapp. Grønlands geol. Unders. 133, $13-26$.

Jell, P. A. \& Stait, B. 1985: Tremadoc trilobites from the Florentine Valley Formation, Tim Shea area, Tasmania. Mem. Mus. Victoria 46, 1-34.

Kerr, J. W. 1968: Stratigraphy of central and eastern Ellesmere Island, Arctic Canada. Part II Ordovician. Pap. geol. Surv. Canada 67-27(2), 92 pp.

Kobayashi, T. 1934: The Cambro-Ordovician formations and faunas of South Chosen. Part II. Lower Ordovician faunas. J. Fac. Sci. Univ. Tokyo Sec. 2, 3(9), 524-585. 
Kobayashi, T. 1940: Lower Ordovician fossils from Junee, Tasmania. Pap. Proc. R. Soc. Tasm. [for 1939], 61-66.

Kobayashi, T. 1955: The Ordovician fossils from the McKay Group in British Columbia, western Canada, with a note on the Early Ordovician palaeogeography. J. Fac. Sci. Univ. Tokyo Sec. 2, 9(3), 356-493.

Koch. L. 1929a: Stratigraphy of Greenland. Meddr Grønland 73(2), 2, 205-320.

Koch, L. 1929b: The geology of the south coast of Washington Land. Meddr Grønland 73(1), 1, 39 pp.

Koch, L. 1940: Survey of North Greenland. Meddr Grønland 130(1), $364 \mathrm{pp}$.

Kurtz, V. E. 1977: Trans-cratonic correlation of early Ordovician conodont Faunas B and C between Northwest Greenland and western United States. Abstr. geol. Soc. Am. 9, 618 only.

Kurtz, V. E. \& Miller, J. F. 1978: Correlation of Lower Ordovician conodont Faunas D and $\mathrm{E}$ between Washington Land, western North Greenland and western United States. Abstr. geol. Soc. Am. 10, 219 only.

Landing, E. Barnes, C. R. \& Stevens, R. K. 1986: Tempo of earliest Ordovician graptolite faunal succession: conodontbased correlations from the Tremadocian of Quebec. Can. J. Earth Sci. 23, 1928-1949.

Peel, J. S. 1982: The Lower Paleozoic of Greenland. Mem. Can. Soc. Petrol. Geol. 8, 309-330.

Peel, J. S. \& Christie, R. L. 1982: Cambrian-Silurian platform stratigraphy: correlations around Kane Basin. Meddr Grønland Geosci. 8, 117-135.
Peel, J. S. \& Cowie, J. W. 1979: New names for Ordovician formations in Greenland. Rapp. Grønlands geol. Unders. 91, 117-124.

Poulsen, C. 1927: The Cambrian, Ozarkian and Canadian faunas of Northwest Greenland. Meddr Grønland 70(1), 2, 237-343.

Poulsen, C. 1937: On the Lower Ordovician faunas of East Greenland. Meddr Grønland 119(3), 72 pp.

Ross, R. J. 1951: Stratigraphy of the Garden City Formation in northeastern Utah, and its trilobite faunas. Bull. Peabody Mus. nat. Hist. 6, 155 pp.

Scotese, C. R. In McKerrow, W. S. \& Scotese, C. R. (edit.) in press: Palaeozoic palaeogeography. Mem. geol. Soc. London.

Sønderholm, M. \& Due, P. H. 1985: Lower and Middle Ordovician platform carbonate lithostratigraphy of Warming Land, Wulff Land and Nares Land, North Greenland. Rapp. Grønlands geol. Unders. 126, 31-46.

Troelsen, J. C. 1950: Contributions to the geology of Northwest Greenland, Ellesmere Island and Axel Heiberg Island. Meddr Grønland 149(7), 86 pp.

Troelsen, J. C. 1956: Groenland - Greenland Lexique stratigraphique international Vol. 1. Europe, fasc. I a, 116 pp. Paris: C.N.R.S.

Ulrich. E. O. In Bridge, J. 1930: Geology of the eminence and Carareva quadrangles. Bull. geol. Surv. Missouri 2nd ser., 24, $228 \mathrm{pp}$.

Zhou, Z.-Y. \& Fortey, R. A. 1986: Ordovician trilobites from North and Northeast China. Palaeontographica A, 192, $157-$ 210. 